\title{
Particle Size Analysis of Different Clay Types and Investigation of their Important Characteristics
}

\author{
Suresh Aluvihara*, C. S. Kalpage \\ Department of Chemical and Process Engineering, University of Peradeniya, Peradeniya, Sri Lanka
}

*Corresponding author: Suresh Aluvihara

\section{Abstract}

Clay is an earth resource which is taken as a raw material for a vast range of industrial applications because of peerless properties of such clay. Analysis of the particle size distributions of anthill clay, brick clay and roof tile clay with the important parameters were the aims and objectives of the existing research. In the dry sieve analysis, ASTM D422 standard methodology was followed while performing a microscopic analysis of each type of clay using an optical microscope. Based on the requirements of the testing of water absorption and splitting tensile loads, bricks were manufactured from each clay type. As the major outcomes of the existing investigation, there were obtained well graded particle arrangement from roof tile clay, gap graded arrangement from anthill clay and uniformly graded arrangement from anthill clay, lowest $\mathrm{P}^{\mathrm{H}}$ value from anthill clay, maximum splitting tensile load from roof tile clay brick, maximum water absorption from anthill clay brick, maximum natural moisture content from roof tile clay and relatively higher finer weight percentage of particles from roof tile clay under both microscopic analysis and sieve analysis.

Keywords: Anthill clay, Brick clay, Roof tile clay, Particle size, Sieve analysis.

Copyright @ 2020: This is an open-access article distributed under the terms of the Creative Commons Attribution license which permits unrestricted
use, distribution, and reproduction in any medium for non-commercial use (NonCommercial, or CC-BY-NC) provided the original author and source
are credited.
are credited.

\section{INTRODUCTION}

Clay is a noticeable earth material which is found from various locations on the earth surface although having various properties mainly due to the occurrences. According to the classification of rocks, clay is a bulk of debris of sedimentary rocks that formed as a result of weathering of large rocks.

As a result of transportation and accumulation of weathering rock debris, the clay soil was formed while obtaining some unique physic- chemical properties when comparing with other soil types such as the high porosity and less permeability [1-5].

Clay is a specified group of minerals which is formed as the results of the variations of following basic conditions of some specific locations of the earth.

- Pressure

- Temperature

- Physicochemical conditions

Those are the volatile conditions that based on the location and the climatic conditions [2-4].
Based on the variations of some specific physico-chemical properties of such clays, those clays are applicable in various industrial purposes such as the food containers, water treatment, ceramic industries and pottery industries [4-10].

When comparing the physico-chemical properties of clays, especially it is relatively less permeable and consisted with large number of pores when comparing with those behaviors of other common soil species. In addition that grain size of some clay/ soil is an important parameter and selection criteria that based on the industrial applications [4-18].

The investigation of the important physicochemical chemical properties of some particular clay type is an essential stuff prior to the deciding of such material for some suitable application.

\section{MATERIALS AND METHODOLOGY}

According to the aims and objectives of the existing research, three different types of clays were selected and the representative samples were collected from where the available places. The selected clay types are given in the below. 
- Anthill clay-clay that using in the building of anthill by termites

- Brick clay -clay that using in the manufacturing of bricks

- Roof tile clay -clay that using in the manufacturing of roof tiles
In the collection of the representing clay samples, the anthill clay sample was collected nearby Matale area, the brick clay sample was collected from Maduragoda area in Kurunegala district and the roof tile clay sample was collected from Dankotuwa area in Puttalam district. The sample collected areas are shown in the Figure-1.

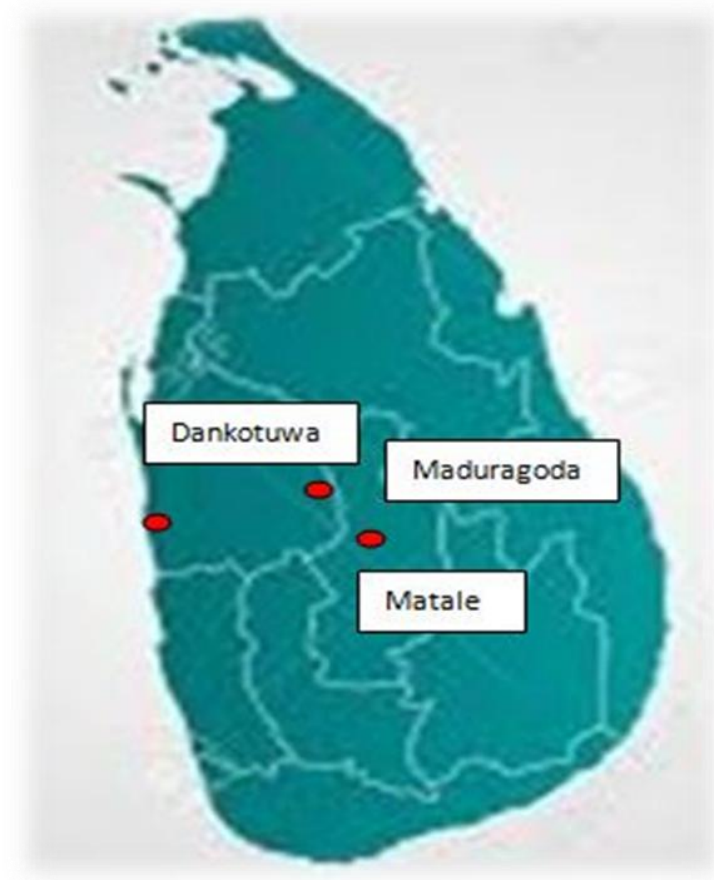

Fig-1: Sample collected areas

Physical and visible descriptions of those clay samples are given in the Table- 1 .

Table-1: Physical and visible description of clay samples

\begin{tabular}{|l|l|l|}
\hline Clay Sample & Location & Physical and visible description \\
\hline Anthill clay & Matale & Reddish brown color, smooth and tiny particles and slightly fizzed with water \\
\hline Brick clay & Maduragoda & Brown color, rough and relatively coarse particles, relatively impure \\
\hline Roof tile clay & Dankotuwa & Yellowish brown color, very smooth and tiny particles, slowly dissolved in water \\
\hline
\end{tabular}

The selected clay types are shown in the following figures.

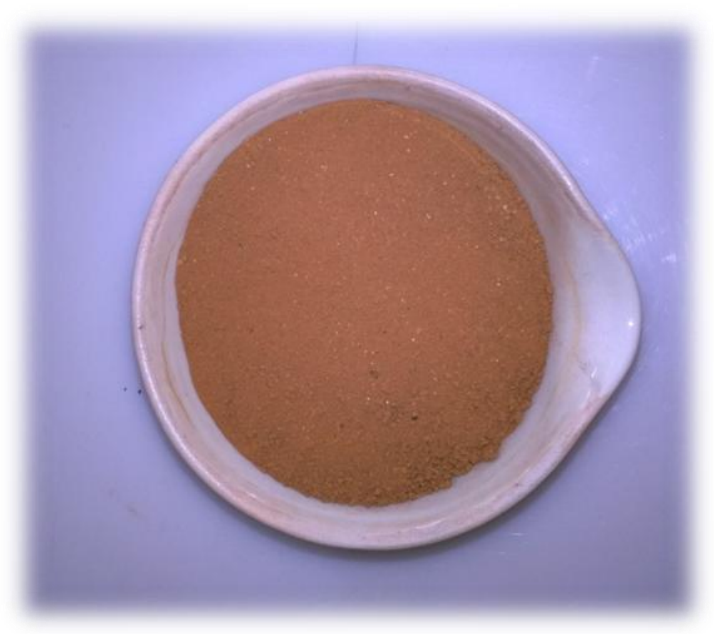

Fig-2: Anthill clay

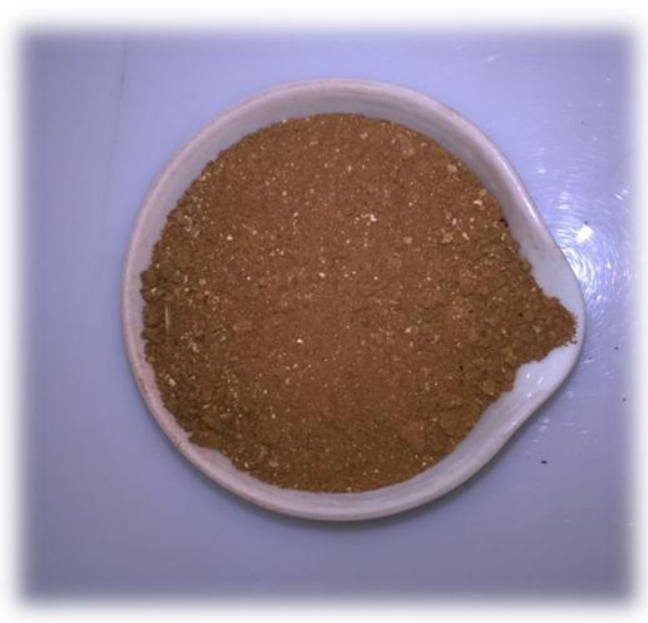

Fig-3: Brick clay 


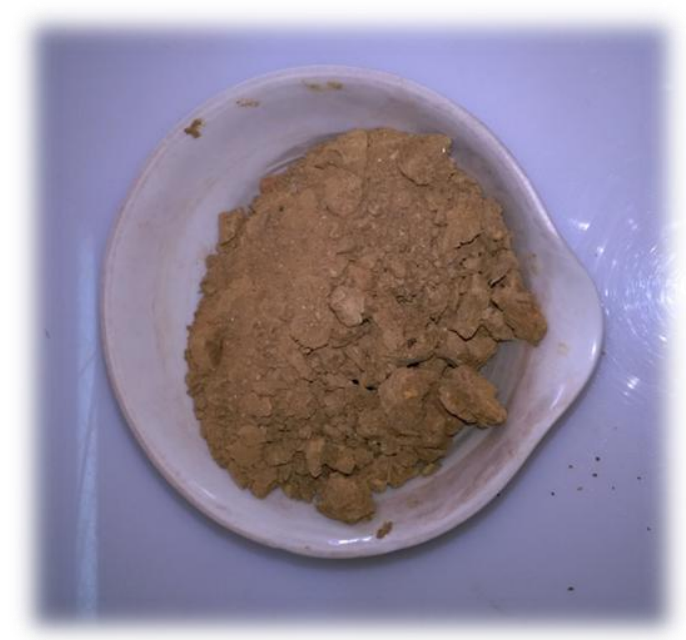

Fig-4: Roof tile clay

\section{Natural Moisture Content}

A small portion of clay was selected from each type of clay and the initial weights of each representative samples were measured by an analytical balance. The representative clay samples were oven dried for 24 hours under the temperature of $110^{\circ} \mathrm{C}$. The final weights of dried clay samples were measured using the same analytical balance and the natural moisture contents of each clay sample were determined using the following equation [1-5].

Moisture content $=\left\{\left(\mathrm{M}_{\mathrm{I}^{-}} \mathrm{M}_{\mathrm{F}}\right) / \mathrm{M}_{\mathrm{I}}\right\} * 100 \%$

Where,

$\mathrm{M}_{\mathrm{I}}=$ Initial weight of the clay sample/g

$\mathrm{M}_{\mathrm{F}}=$ Final weight of the clay sample/g

The drying oven has been shown in the Figure-5.

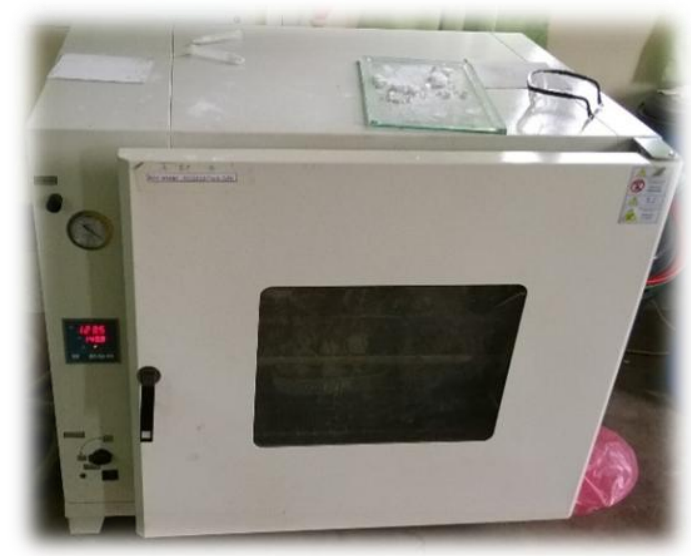

Fig-5: Drying oven

\section{Dry Sieve Analysis}

After carried out to the laboratory, a sufficient amount of raw clay was taken from each clay sample and those samples were put separately into three of cleaned aluminum trays. The three separated clay samples were put into the oven and dried until the weight was getting constant under the temperature $110^{\circ} \mathrm{C}$. After drying, each clay sample was crushed in a ceramic crucible for approximately 30 minutes until those samples were becoming free from unusual coarse particles/ colloids $[1,2,5]$.

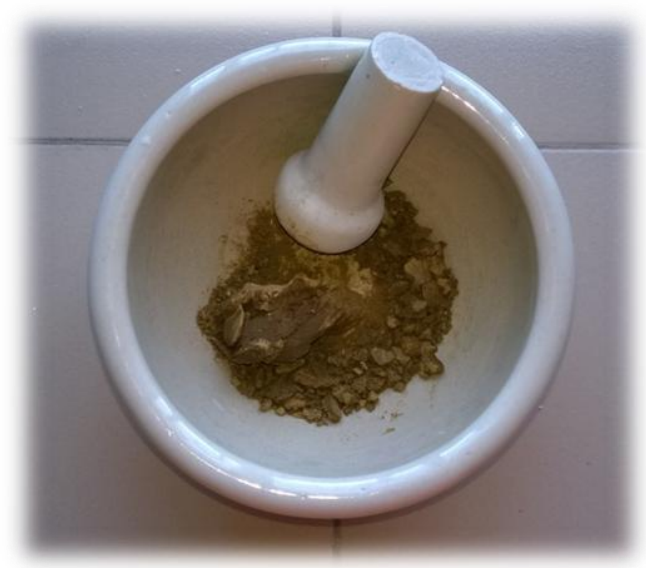

Fig-6: Ceramic crucible

According to the standard methodology for the sieve analysis ASTM D422, three different clay samples were analyzed with the list of apparatus as given in the below.

- Analytical balance

- Set of sieves

- Wire brush (cleaning brush)

- Sieve shaker

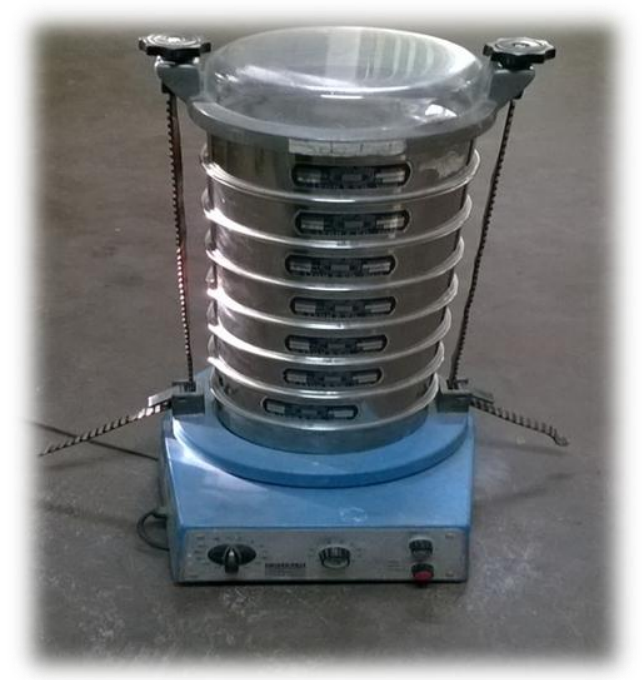

Fig-7: Set of apparatus

According to the graphs and observations, determinations of effective size, uniformity coefficient, coefficient of gradation and sorting coefficient were done with respect to each type of clay using following definitions and equations $[1-3,5,10]$.

Effective size $=D_{10}$

Where,

$\mathrm{D}_{10}=$ Diameter corresponding to $10 \%$ finer percent in the particle size distribution curve $/ \mathrm{mm}$

$\mathrm{C}_{\mathrm{u}}=\mathrm{D}_{60} / \mathrm{D}_{10}$ 
Where,

$\mathrm{C}_{\mathrm{u}}=$ Uniformity coefficient

$\mathrm{D}_{60}=$ Diameter corresponding to $60 \%$ finer percent in the particle size distribution curve $/ \mathrm{mmD}_{10}=$ Diameter corresponding to $10 \%$ finer percent in the particle size distribution curve $/ \mathrm{mm}$

$\mathrm{C}_{\mathrm{c}}=\left(\mathrm{D}_{30}\right)^{2} /\left(\mathrm{D}_{60} * \mathrm{D}_{10}\right)$

Where,

$\mathrm{C}_{\mathrm{u}}=$ Coefficient of gradation

$\mathrm{D}_{60}=$ Diameter corresponding to $60 \%$ finer percent in the particle size distribution curve $/ \mathrm{mm}$

$\mathrm{D}_{30}=$ Diameter corresponding to $30 \%$ finer percent in the particle size distribution curve $/ \mathrm{mm}$

$\mathrm{D}_{10}=$ Diameter corresponding to $10 \%$ finer percent in the particle size distribution curve $/ \mathrm{mm}$

$\mathrm{S}_{0}=\left(\mathrm{D}_{75} / \mathrm{D}_{25}\right)^{1 / 2}$

Where,

$\mathrm{S}_{0}=$ Sorting coefficient

$\mathrm{D}_{25}=$ Diameter corresponding to $25 \%$ finer percent in the particle size distribution curve $/ \mathrm{mm} \mathrm{D}_{75}=$ Diameter corresponding to $75 \%$ finer percent in the particle size distribution curve $/ \mathrm{mm}$

\section{Microscopic Analysis}

A small representative portion of each clay sample was randomly taken. The selected representative clay samples were well dried using an oven at the temperature of $110^{\circ} \mathrm{C}$ and crushed. A small portion of clay from each prepared sample was placed on a cleaned glass slide and the glass slide was sent for the microscopic analysis using $20 \mathrm{X}$ lens of an optical microscope as shown in the Figure-7.

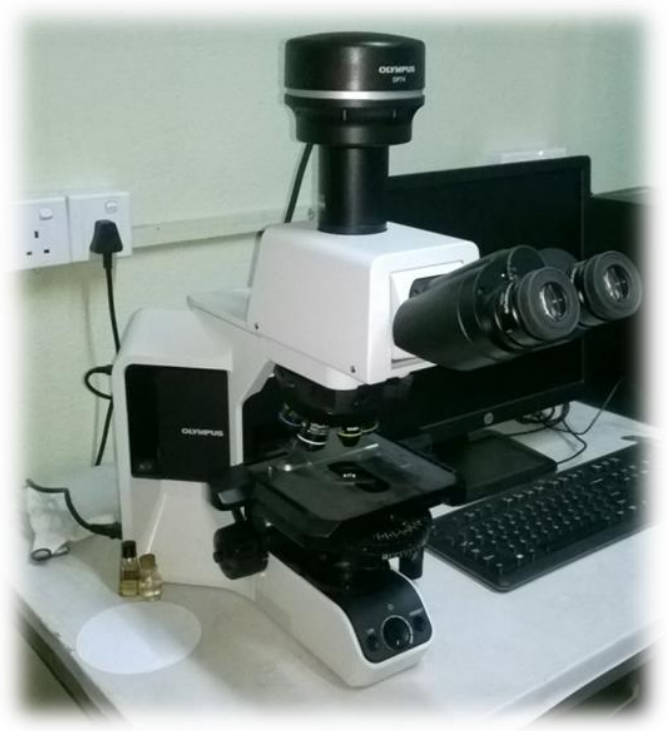

Fig-8: Optical microscope

\section{Manufacturing of Bricks}

In the manufacturing of bricks, the traditional methodology was followed also in the existing research. The sufficient portions from each type of raw clay masses were separately collected and manually tanned while gradually adding water for enough time periods.

The well tanned and wetted clay masses were separately placed in prepared wooden moulds in similar sizes dimensionally as $10 \mathrm{~cm}^{*} 6 \mathrm{~cm}^{*} 1.5 \mathrm{~cm}$. Those clay masses were allowed to desiccate under the normal atmospheric conditions especially absence of direct sunlight approximately for seven days.

The dried clay masses were carefully removed from the moulds and oven dried for six hours under the temperature of $110^{\circ} \mathrm{C}$ until getting constant weights [1, $3,5,10]$.

The well dried clay masses were fired using a muffle furnace under the firing temperature of $800^{\circ} \mathrm{C}$ approximately for ten hours period and the fired clay masses were gently allowed to cool up to the normal condition and those are called as bricks $[8,9,15,17$, $18]$.

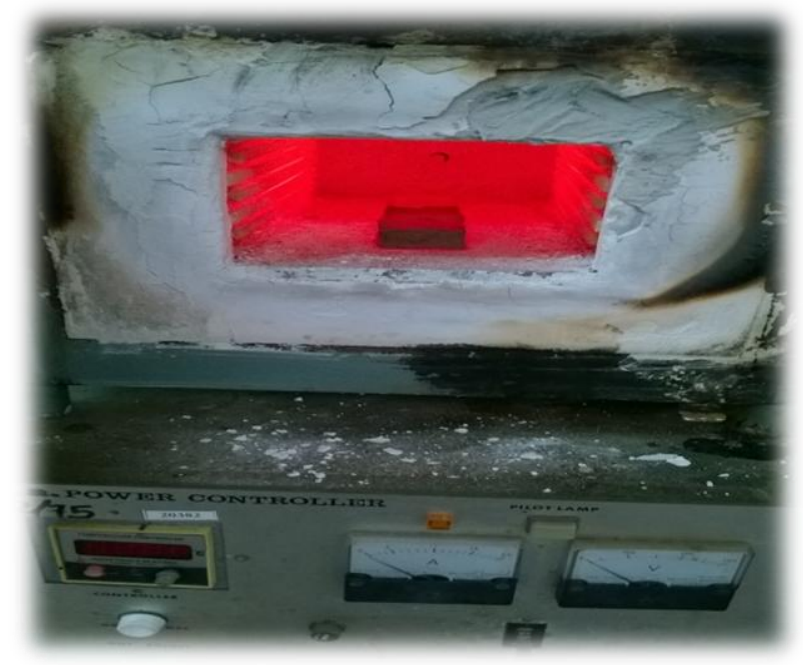

Fig-9: Firing of bricks

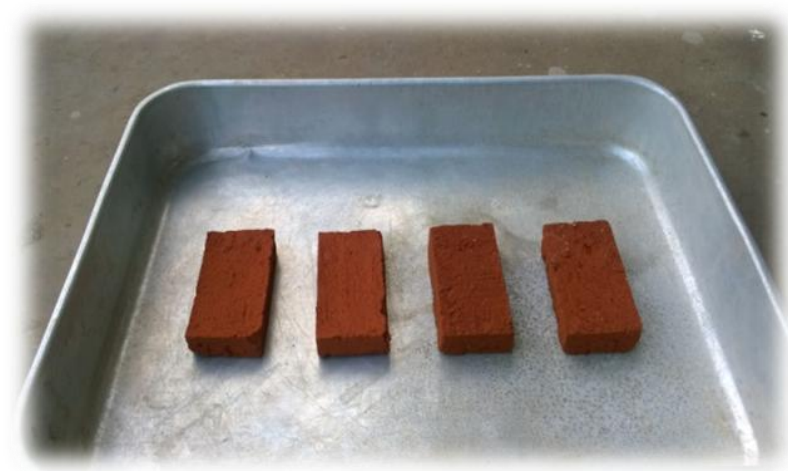

Fig-10: Manufactured bricks 


\section{Water Absorption of Bricks}

Prepared bricks were dried in the oven for a few hours under the temperature $110^{\circ} \mathrm{C}$ and the dried bricks were allowed until getting cold under normal conditions [1-3,5]. The initial weight of each type of brick was measured using an analytical balance. The bricks were completely immersed in water which were remaining under the room temperature. After 24 hours immersion time period the final weight of each wetted brick was measured using the same analytical balance. The water absorption of each brick was determined using following equation.

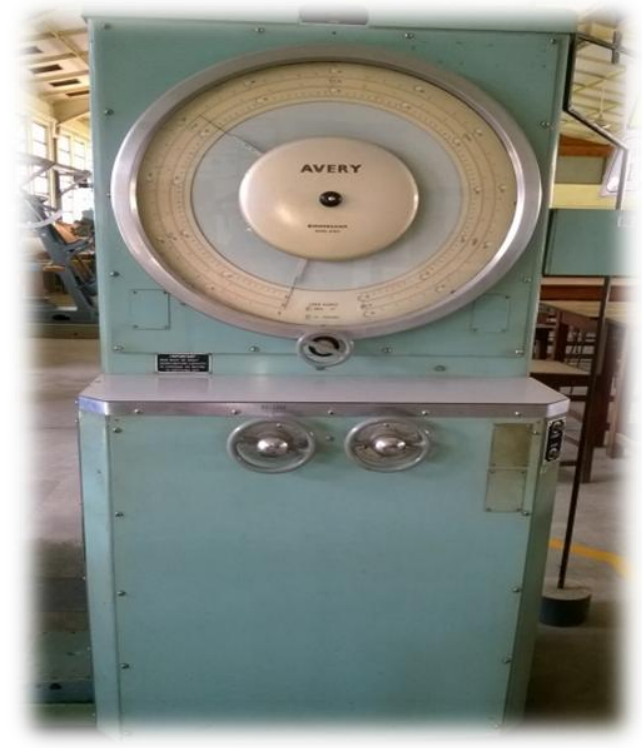

Fig-11: Universal tensile strength testing machine

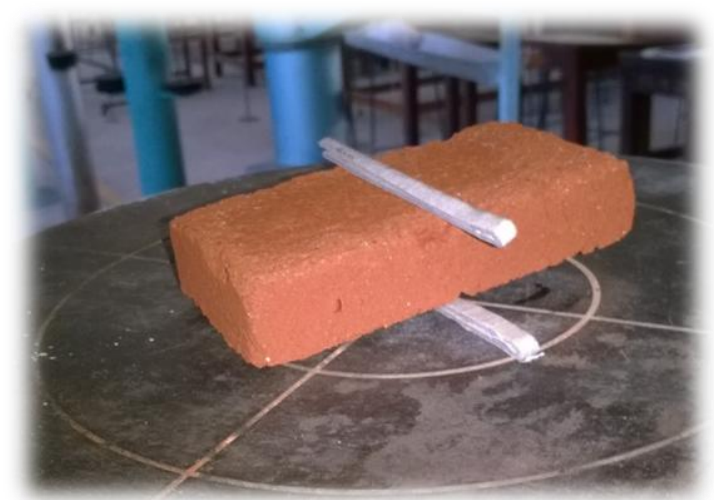

Water absorption $=\left\{\left(\mathrm{M}_{\mathrm{W}^{-}} \mathrm{M}_{\mathrm{D}}\right) / \mathrm{M}_{\mathrm{D}}\right\} * 100 \%$

Where,

$\mathrm{M}_{\mathrm{D}}=$ Dry weight of the brick/g

$\mathrm{M}_{\mathrm{w}}=$ Wetted weight of the brick/g

\section{Splitting Tensile Load}

The splitting tensile load of each type brick was measured using universal tensile strength testing machine which is shown in the Figure-9 [17].

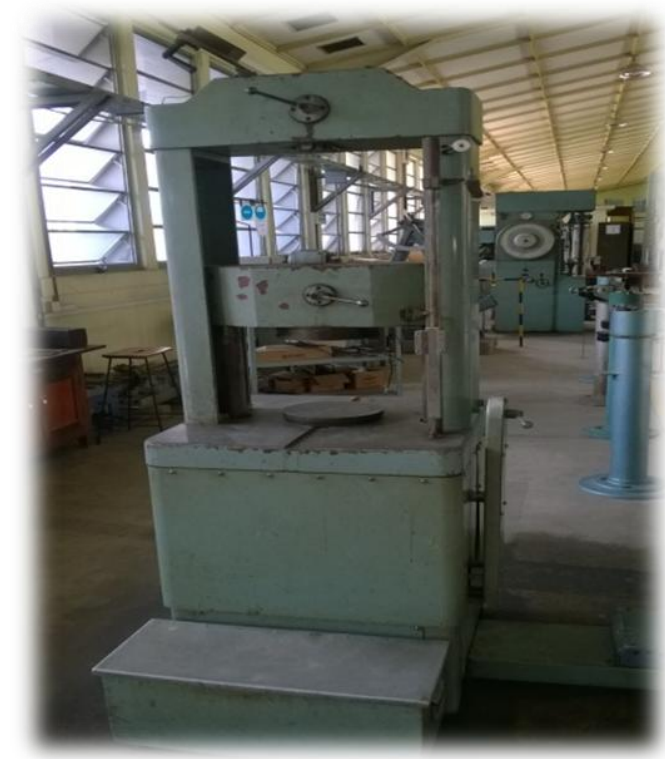

Fig-12: Universal tensile strength testing machine

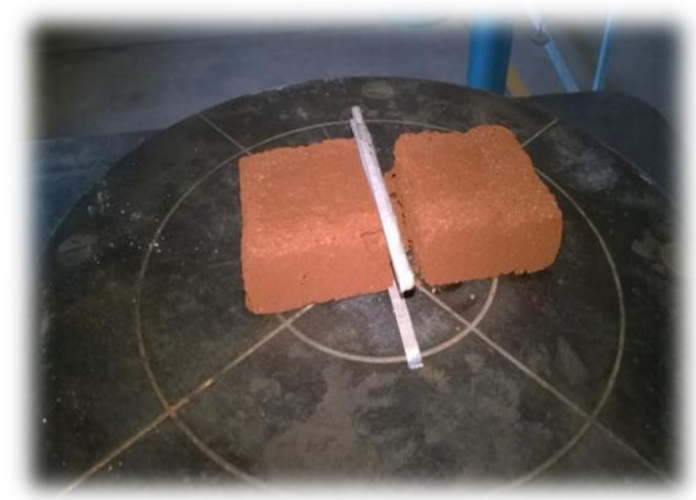

Fig-13: Splitting of a brick after applying of a load

\section{Acidities of Clays}

Acidity of clay is an important parameter to be considered prior to the most of industrial applications especially for the applications of food containers and water treatments because such property is interrelated with the quality of such food or water after interaction with clay.

As the methodology for the investigations of the acidities of clays, $5 \mathrm{~g}$ of clay sample from each clay type was measured and separately dissolved in $50 \mathrm{ml}$ volumes of distilled water. Each clay solution was stirred well for 15 minutes using a stirrer.

The $\mathrm{P}^{\mathrm{H}}$ values of each clay solution were measured using a digital $\mathrm{P}^{\mathrm{H}}$ meter while measuring the $\mathrm{P}^{\mathrm{H}}$ value of the distilled water as a reference value.

\section{RESULTS AND DISCUSSION Natural Moisture Content}

The results for the measuring of moisture contents of clays have been given in the Table-1. 
Table-1: Moisture contents of clays

\begin{tabular}{|l|l|l|l|}
\hline Clay Type & Anthill clay & Brick clay & Roof tile clay \\
\hline Moisture Content (\%) & 14.49 & 21.45 & 25.97 \\
\hline
\end{tabular}

According to the obtained results, it was observed the highest natural moisture content from the roof tile clay since lower amount of moisture was finding from anthill clay. However, the natural moisture content is not a measurement which is only depending on the internal properties of the material/ clay because some external conditions might be played a role of regulating of the natural moisture content of some clay/material as given in the below $[1,3,4,5,10]$.

- Climatic conditions
- Geological conditions

- Environmental conditions

Therefore, the obtained results can be only used as an indicator of the water holding capacity of such clay or material even though it is not much useful for further explanation without knowing the other external conditions of the location.

\section{Water Absorption}

Table-2: Water absorption of the bricks

\begin{tabular}{|l|l|l|l|}
\hline Clay Type of the Brick & Anthill Clay & Brick Clay & Roof Tile Clay \\
\hline Water Absorption (\%) & 24.93 & 19.88 & 17.30 \\
\hline
\end{tabular}

The obtained results showed the highest water absorption from the brick which was prepared by the anthill clay while the roof tile clay brick was showing the lowest water absorption among three types of bricks.

The water absorption is some sort of definable measurement regarding the water holding capacity of such material because the experiment was performed under same conditions for different types of materials instead of exposing to different environment.

\section{Splitting Tensile Load} Table-2.

Splitting tensile loads of bricks are given in the

Table-2: Splitting tensile loads of bricks

\begin{tabular}{|l|l|}
\hline Clay of the Brick & Splitting Load (lb) \\
\hline Anthill Clay & 155 \\
\hline Brick Clay & 110 \\
\hline Roof Tile Clay & 460 \\
\hline
\end{tabular}

In the comparison of the splitting tensile loads of bricks which were prepared by three different clay types, the roof tile clay brick showed relatively huge splitting tensile load rather than other two types of bricks.

Therefore, the roof tile clay is much suitable for the large strength and load holding purposes when comparing with the other clay types in the current research. When comparing the splitting tensile load with the particle arrangement of roof tile clay, the lower grain sized clays/soils are much stronger in the structure of bricks [1, 3, 14, 17].

\section{Acidities of Clays}

Temperature of the solutions and distilled water is $25.4^{0} \mathrm{C}$ and the $\mathrm{P}^{\mathrm{H}}$ value of the distilled water is 7.00. The obtained results for the acidities of three different types of clays were shown in the Table-2.

Table-2: Acidities of clays

\begin{tabular}{|l|l|}
\hline Clay Type & $\mathbf{P}^{\mathrm{H}}$ \\
\hline Anthill Clay & 5.56 \\
\hline Brick Clay & 6.57 \\
\hline Roof Tile Clay & 5.68 \\
\hline
\end{tabular}

By referring the above results, it seems the relatively highest acidity (lowest $\mathrm{P}^{\mathrm{H}}$ value) from the anthill clay while the lowest acidity (highest $\mathrm{P}^{\mathrm{H}} \sim 7$ ) was obtaining from the brick clay.

In the applications of food packing and water treatment, the material is directly interacted with the food or water and the quality of such food or water is quietly important in the investigation of human health. Therefore, the anthill clay is bit hazardous for the most of water treatment and some food industries because of the relatively higher acidity when comparing with the conditions of other different clay types in the existing investigation. However, the properties of the clay may be varied with the location and other soil and rock species of the location and adjacent background.

\section{Particle Size Analysis}

According to the dry sieve analysis, the obtained results and essential determinations have been shown in the following tables. 
Table-2: Particle size distribution of anthill clay

\begin{tabular}{|l|l|l|l|l|}
\hline $\begin{array}{l}\text { Sieve Size } \\
(\mathbf{m m})\end{array}$ & $\begin{array}{l}\text { Weight retained on } \\
\text { each sieve (g) }\end{array}$ & $\begin{array}{l}\text { Percentage of weight } \\
\text { retained (\%) }\end{array}$ & $\begin{array}{l}\text { Cumulative percentage of } \\
\text { weight retained (\%) }\end{array}$ & $\begin{array}{l}\text { Percent Finer } \\
(\%)\end{array}$ \\
\hline 2 & 0.02 & 0.04 & 0.04 & 99.96 \\
\hline 0.5 & 10.34 & 20.32 & 20.36 & 79.64 \\
\hline 0.25 & 15.61 & 30.68 & 51.04 & 48.96 \\
\hline 0.149 & 12.39 & 24.35 & 75.39 & 24.61 \\
\hline 0.074 & 3.91 & 7.68 & 83.08 & 16.92 \\
\hline 0.037 & 7.86 & 15.45 & 98.53 & 1.47 \\
\hline Pan & 0.75 & 1.47 & 100 & 0.00 \\
\hline Total & $\mathbf{5 0 . 8 8}$ & $\mathbf{1 0 0}$ & \multicolumn{2}{|l}{} \\
\cline { 1 - 2 }
\end{tabular}

Table-3: Particle size distribution of brick clay

\begin{tabular}{|l|l|l|l|l|}
\hline $\begin{array}{l}\text { Sieve Size } \\
(\mathbf{m m})\end{array}$ & $\begin{array}{l}\text { Weight retained on } \\
\text { each sieve }(\mathbf{g})\end{array}$ & $\begin{array}{l}\text { Percentage of weight } \\
\text { retained (\%) }\end{array}$ & $\begin{array}{l}\text { Cumulative percentage of } \\
\text { weight retained (\%) }\end{array}$ & $\begin{array}{l}\text { Percent Finer } \\
(\boldsymbol{\%})\end{array}$ \\
\hline 2 & 0.01 & 0.02 & 0.02 & 99.98 \\
\hline 0.5 & 10.41 & 20.30 & 20.32 & 79.68 \\
\hline 0.25 & 17.13 & 33.41 & 53.74 & 46.26 \\
\hline 0.149 & 13.43 & 26.19 & 79.93 & 20.07 \\
\hline 0.074 & 7.09 & 13.83 & 93.76 & 6.24 \\
\hline 0.037 & 2.47 & 4.82 & 98.58 & 1.42 \\
\hline Pan & 0.73 & 1.42 & 100 & 0.00 \\
\hline Total & $\mathbf{5 1 . 2 7}$ & $\mathbf{1 0 0}$ & \multicolumn{2}{|l}{} \\
\cline { 1 - 2 }
\end{tabular}

Table-4: Particle size distribution of roof tile clay

\begin{tabular}{|l|l|l|l|l|}
\hline $\begin{array}{l}\text { Sieve Size } \\
(\mathbf{m m})\end{array}$ & $\begin{array}{l}\text { Weight retained on } \\
\text { each sieve (g) }\end{array}$ & $\begin{array}{l}\text { Percentage of weight } \\
\text { retained (\%) }\end{array}$ & $\begin{array}{l}\text { Cumulative percentage of } \\
\text { weight retained (\%) }\end{array}$ & $\begin{array}{l}\text { Percent Finer } \\
(\%)\end{array}$ \\
\hline 2 & 0.16 & 0.31 & 0.31 & 99.69 \\
\hline 0.5 & 11.8 & 23.17 & 23.48 & 76.52 \\
\hline 0.25 & 7.97 & 15.65 & 39.13 & 60.87 \\
\hline 0.149 & 11.71 & 22.99 & 62.12 & 37.88 \\
\hline 0.074 & 11.12 & 21.83 & 83.96 & 16.04 \\
\hline 0.037 & 7.05 & 13.84 & 97.80 & 2.20 \\
\hline Pan & 1.12 & 2.20 & 100 & 0.00 \\
\hline Total & $\mathbf{5 0 . 9 3}$ & $\mathbf{1 0 0}$ & \multicolumn{2}{|l}{} \\
\cline { 1 - 2 }
\end{tabular}

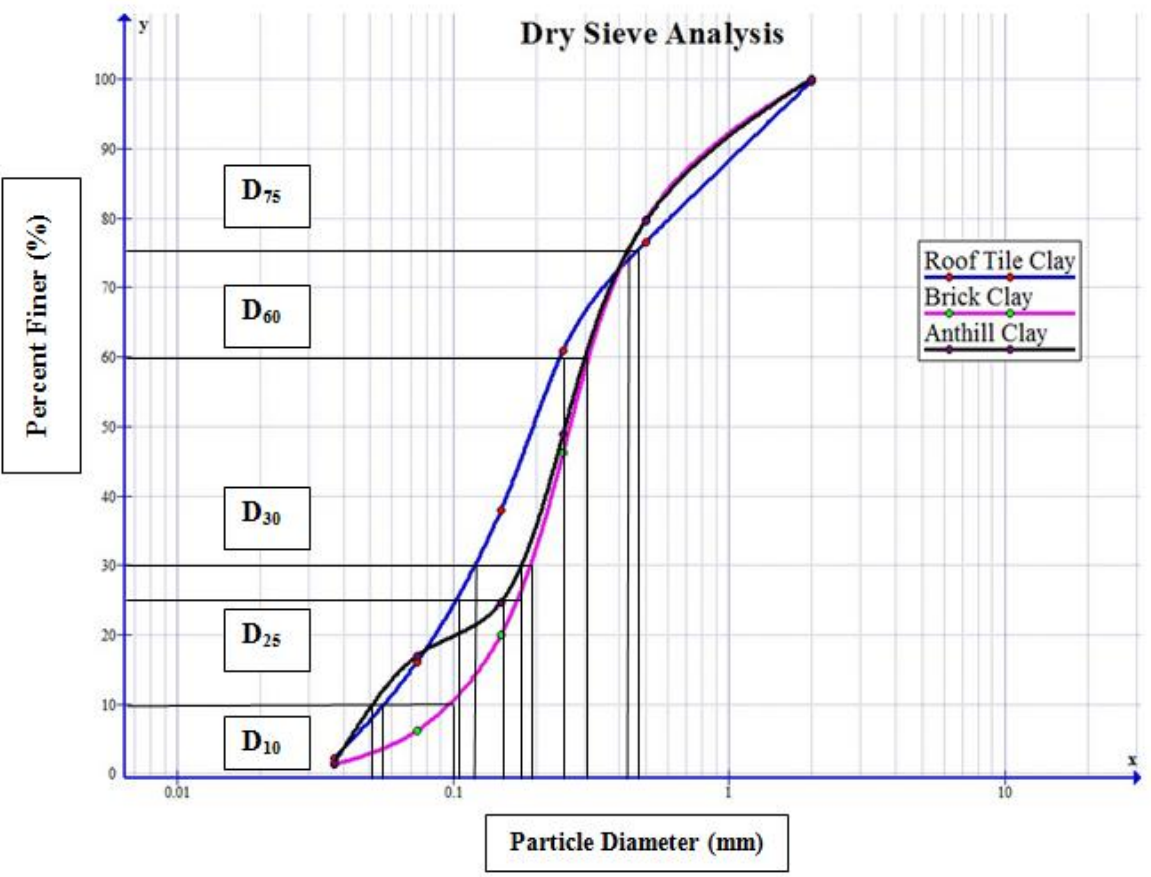

Fig-14: Particle size distribution curves of three different clay types 
By referring the above particle size distribution curves of three different types of clays, some useful readings were recorded and shortlisted as shown in the Table 4.

Table-4: The important observations that recorded from the particle size distribution curves

\begin{tabular}{|l|l|l|l|l|l|}
\hline Type of Clay & $\mathbf{D}_{\mathbf{1 0}}(\mathbf{m m})$ & $\mathbf{D}_{\mathbf{2 5}}(\mathbf{m m})$ & $\mathbf{D}_{\mathbf{3 0}}(\mathbf{m m})$ & $\mathbf{D}_{\mathbf{6 0}}(\mathbf{m m})$ & $\mathbf{D}_{\mathbf{7 5}}(\mathbf{m m})$ \\
\hline Anthill Clay & 0.051 & 0.146 & 0.175 & 0.295 & 0.425 \\
\hline Brick Clay & 0.096 & 0.170 & 0.192 & 0.310 & 0.433 \\
\hline Roof Tile Clay & 0.055 & 0.103 & 0.119 & 0.245 & 0.470 \\
\hline
\end{tabular}

Depending on above observations and data, following important parameters were determined using standard equations and definitions for each type of clay and the relevant results were given in the Table-5.

Table-5: The determined important parameters of clays

\begin{tabular}{|l|l|l|l|l|}
\hline Type of Clay & $\begin{array}{l}\text { Effective Size/ } \\
\mathbf{D}_{\mathbf{1 0}}(\mathbf{m m})\end{array}$ & $\begin{array}{l}\text { Uniformity } \\
\text { Coefficient } / \mathbf{C}_{\mathbf{u}}\end{array}$ & $\begin{array}{l}\text { Coefficient of } \\
\text { Gradation/C }_{\mathbf{c}}\end{array}$ & $\begin{array}{l}\text { Sorting } \\
\text { Coefficient/ } \mathbf{S}_{\mathbf{0}}\end{array}$ \\
\hline Anthill Clay & 0.051 & 5.78 & 2.04 & 1.71 \\
\hline Brick Clay & 0.096 & 3.23 & 1.24 & 1.60 \\
\hline Roof Tile Clay & 0.055 & 4.45 & 1.05 & 2.12 \\
\hline
\end{tabular}

In the comparison of the patterns of particle size distribution curves of three different types of clays, there were mainly identified well graded arrangement of particles in roof tile clay, gap graded arrangement of particles in anthill clay and uniformly graded arrangement of particles in brick clay [1-7].

When considering the effective sizes $\left(D_{10}\right)$ of these clay types, the maximum value was found from brick clay particles while observing relatively lower effective sizes from both anthill clay and roof tile clay. Based on those observations that it is possible to be concluded some uniformly graded particle arrangement in the mass of brick clay also including more pores even though the shapes of particles play a drastic role in the regulations of the spaces between particles [3-9].

In the analysis of the determined uniformity coefficients $\left(\mathrm{C}_{\mathrm{u}}\right)$ of three different clays the maximum and minimum values were obtained accordingly from anthill clay and brick clay. According to such results, it is feasible to approach to some decisions that the poorly grading of particles in brick clays as usual and well grading of particles in anthill clay although there were observed some gap graded arrangement of particles from anthill clay through the particle size distribution curve. When considering the particle size distribution curve of anthill clay, the curve was broken from the middle part of the curve and there were shown two different patterns. Then these kinds of patterns must be analyzed based on the particle size ranges and should be reached for some concessionary decision [2-12].

The coefficient of gradation $\left(\mathrm{C}_{\mathrm{c}}\right)$ is a noticeable parameter regarding the arrangement of grains of a type of soil/clay. Usually for the well graded soils/clays it seems that the coefficient of gradation is more recent to one $\left(\mathrm{C}_{\mathrm{c}} \sim 1\right)$. When comparing the obtained results in the existing experiments, the most well graded arrangement of particles was observed from roof tile clay and the poorly graded particle arrangement was found from anthill clay [2-10].

According to the obtained results for the sorting coefficients $\left(\mathrm{S}_{0}\right)$ of clays, the maximum value was recorded from roof tile clay while the minimum value was recording from brick clay. Therefore, the well grading particle arrangement of roof tile clay should be stronger than other two types of clays [2-16].

As the overall observation and conclusion of the above parameters of the each type of clay, it is possible to expect highest porosity and permeability from brick clay among other clay types. By considering those aspects, it is possible to recommend the brick clay for some advanced applications in water treatments to obtain better performances because high porosity is an essential factor to have a better interaction of water with clay and the high permeability is an important parameter regarding the filtering time.

\section{Microstructure Views}

According to the microscopic analysis of the surfaces of clay samples, the observations have been shown in the following figures.

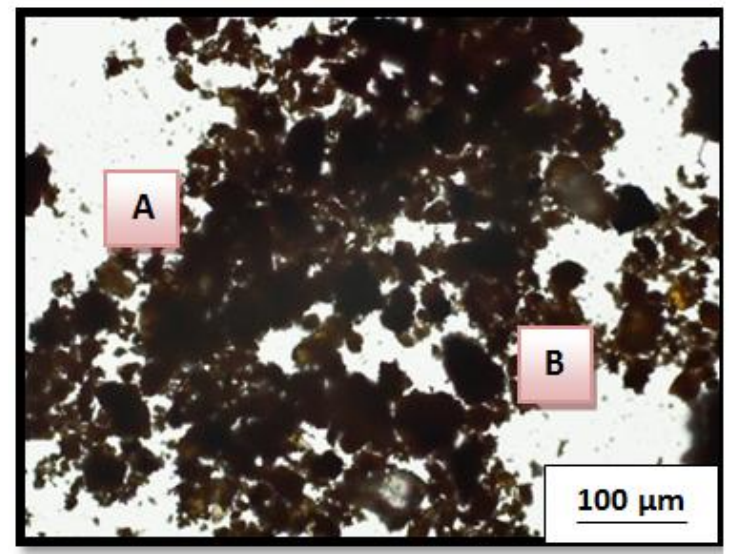

Fig-15: Microstructure of anthill clay 
Suresh Aluvihara \& C. S. Kalpage., Saudi J Eng Technol, April, 2020; 5(4): 163-172

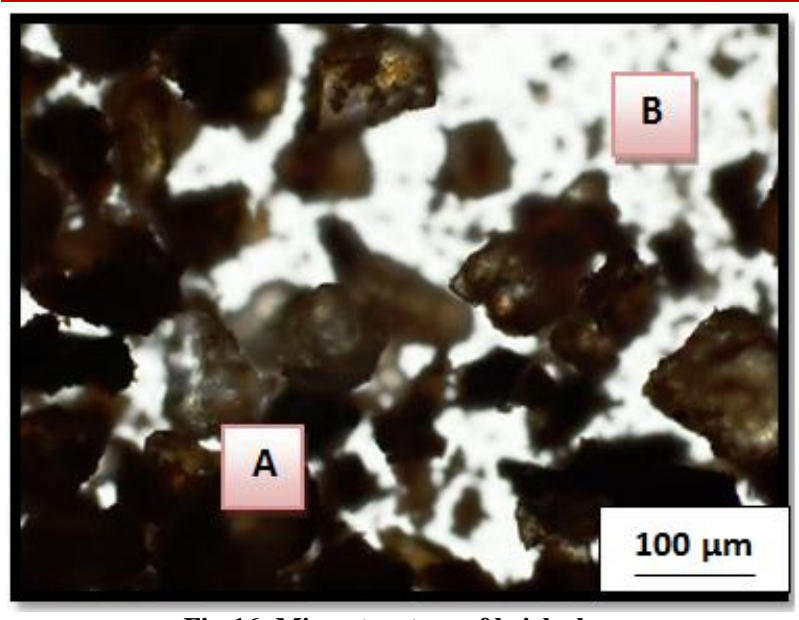

Fig-16: Microstructure of brick clay

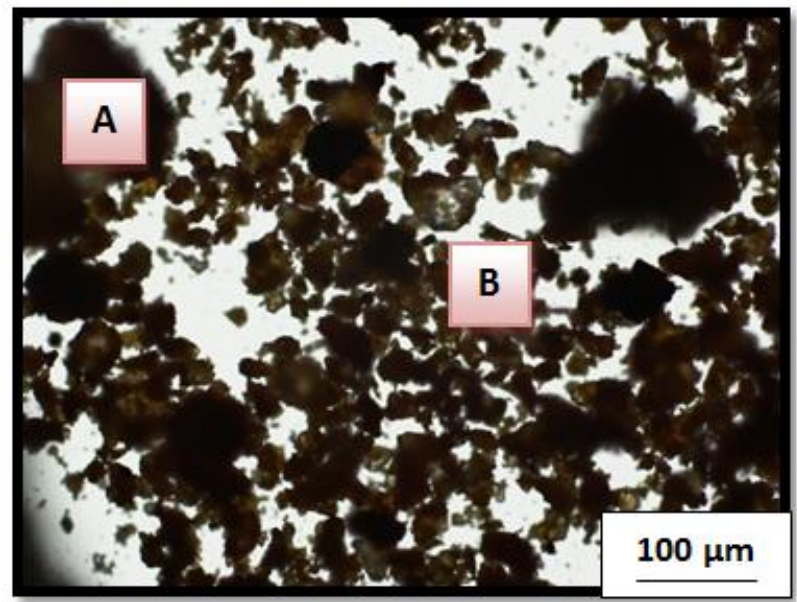

Fig-17: Microstructure of roof tile clay

- A-Coarse particles

- B-Finer particles

Based on the observations of the microstructures of those clays and the obtained results for the particle size analysis (sieve analysis) of such clays, relatively lower sized clay particles were found from roof tile clay while finding relatively higher amount of coarse particles from brick clay.
In the analysis of the shapes of the clay particles, basically some irregular distributions of particles were observed with different shapes of particles including regularly shaped particles and irregularly shaped particles as discussed in the below.

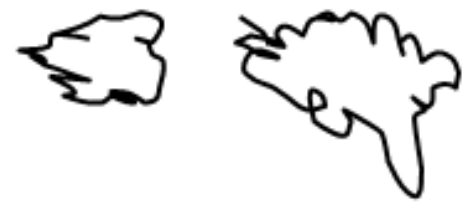

Fig-18: Angular particles

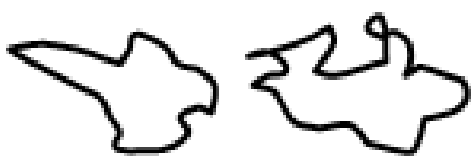

Fig-19: Sub-angular particles
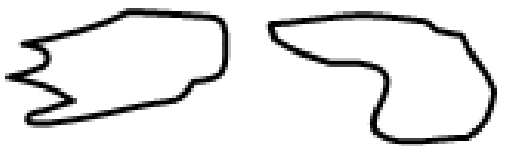

Fig-20: Sub rounded particles

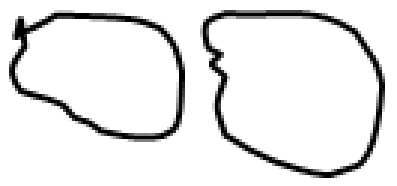

Fig-21: Rounded particles

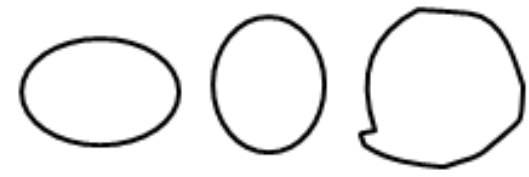

Fig-22: Well rounded particles

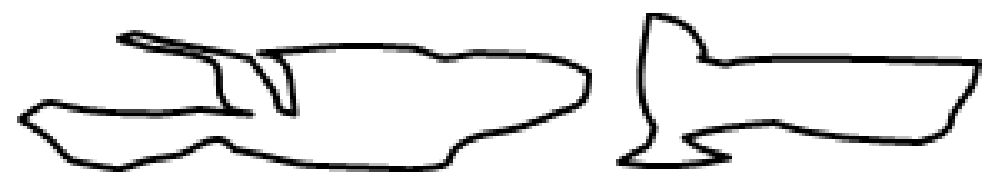

Fig-23: Irregular shaped particles

When the particle shapes of some specific clay/soil are deviated from the rounded and coincidental shapes, it is tended to create much more spaces in between the grains which are called as pores. This is the fundamental status of the most considerable properties of such clay/soil foremost of the porosity [5-18].

\section{CONCLUSION AND RECOMMENDATIONS}

As the major outcomes of the existing investigation, there were observed the maximum finer particle percentage from roof tile clay according to the weight, relatively higher acidity from anthill clay when comparing with the acidities of other clays, relatively higher natural moisture content from roof tile clay, 
highest water absorption from anthill clay brick, maximum splitting tensile load from roof tile clay brick and relatively large sized particle from brick clay and tiny particles from roof tile clay accordingly with the microstructures, gap graded particle arrangement from anthill clay, uniformly (poorly) graded particle arrangement from brick clay and well graded particle arrangement from roof tile clay.

In addition with the existing investigations, there are some useful investigations to be recommended for further researches as given in the below.

- Standard porosity test

- Standard permeability test

- Comparison of those results with the suggestions and conclusions

\section{ACKNOWLEDGEMENT}

The authors wish to compliment the persons those who have provided the materials and institutes that facilitated for the existing research works.

\section{REFERENCES}

1. Akankpo, A. O., \& Stephen, J. O. (2016). Investigation of the Physical Properties of Uruan Clay Soil Used for Manufacturing of Burnt Bricks, Advances in Physics Theories and Applications, 53,18-22.

2. Das, Braja, M. (2010). Principles of Geotechnical Engineering, 7th Edition, Cengage Learning, Stamford, USA.

3. Verma, S. K., Akhtar, S., Shrivastava, S. (2017), Assessment of Particles of Varied Soil By Grain Size Analysis - A Case Study in Jabalpur M.P., International Journal of Engineering Research and Application, 7(7), 32-37. DOI: 10.9790/96220707093237

4. El Fadel, H., Merzouki, M., Faouzi, M., Laamayem, A., Najem, M., \& Benlemlih, M. (2013), Purification Performance of Filtration Process for Leachate in Morocco by Marine Sands, Clays and Fly Ash, Journal of Biotechnology Letters, 4(1), 51-59.

5. Murali, K., Sambath, K., \& Mohammed Hashir S. (2018). A Review on Clay and its Engineering Significance, International Journal of Scientific and Research Publications, 8(2), 8-11.

6. Abdel-Ghafar, H. M., Abdel-Aal, E. A., \& El Anadouli, B. E. (2019), Iron Removal from Ground Water Using Egyptian Cost-Effective Clay Minerals, Applied Chemical Engineering, 2, 1-9. doi:10.24294/ace.v2i1.470.

7. Albracht, B. A., \& Benson C. H. (2001). Effect of desiccation on compacted natural clays. Journal of
Geotechnical and Geoenvironmental Engineering, 127(1), $67-75$.

8. Emmanuel A. O. (2008). Engineering Properties of Locally Manufactured Burnt Brick Pavers for Agrarian and Rural Earth Roads, American Journal of Applied Sciences, 5(10), 1348-1351.

9. Mesida, E. A. (1978). Utilization of some lateritic clays of burnt Bricks, Journal of Mining and Geology, 15(2), 108-114.

10. Dewangan, P. K., Pradhan, M., \& Ramtekkar, G. D. (2015). Effect of Fragment Size, Uniformity Coefficient and Moisture Content on Compaction and Shear Strength Behavior of Coal Mine Overburden Dump Material, European Journal of Advances in Engineering and Technology, 2(12), 1-10.

11. [11]. Umoru, C. I., Shuaibu, A. M., Abdullahi, I. N. and Umar M.U. (2015), Geotechnical Assessment of Gully Erosion at Ankpa Area, North Central Nigeria, IOSR Journal of Applied Chemistry, 8(12), 36-48.

12. Baranowski, R., Rybak, A., \& Baranowska, I. (2002). Speciation Analysis of Elements in Soil Samples by XRF, Polish Journal of Environmental Studies, 11(5), 473-482.

13. Davarcioglu, B. (2010). Investigation of Central Anatolian region NigdeDikilitas (Turkey) clays by FTIR spectroscopy, 62(2), 55-60.

14. De Oliveira1, C. I. R., Rocha, M. C. G., Da Silva, A. L. N., \& Bertolino, L. C. (2016). Characterization of bentonite clays from Cubati, Paraíba (Northeast of Brazil), Cerâmica, 62, 272277.http://dx.doi.org/10.1590/036669132016623631970

15. Cultronea, G., Sebastia'n,E., Kerstin Elert, De La Torre, M. J., Cazallaa, O., \& Rodriguez-Navarro, C. (2004). Influence of mineralogy and firing temperature on the porosity of bricks, Journal of the European Ceramic Society, 24, 547-564. doi:10.1016/S0955-2219(03)00249-8

16. Lakho, N. A., \& Zardari, M.A. (2016) Comparison of Compressive and Tensile Strength of Baked Clay with Those of Normal Concrete. Engineering, 301-307. http://dx.doi.org/10.4236/eng.2016.86027

17. Salman, G. A., \& Salih, S. A. (2018). Effect of Burning Temperature of Clay Bricks Containing Reeds on its Longitudinal Shrinkage, Modulus of Rapture and Thermal Conductivity. International Journal of Civil Engineering and Technology, 9(9), 1388-1402.

18. Rani, J., Singh, K. J., Singh, R., \& Sublania H. (2015), Effect on Microstructure of Clay Bricks after Firing Temperature, Journal of Emerging Technologies and Innovative Research, 2(10), 123-128. 